\title{
Brachial Artery Branch
}

National Cancer Institute

\section{Source}

National Cancer Institute. Brachial Artery Branch. NCI Thesaurus. Code C32227.

Any artery arising from the brachial artery. 